\title{
Georges Didi-Huberman. Remontajes al tiempo padecido. El ojo de la historia 2. Buenos Aires. Editorial Biblos, 2015, 239 pp. Traducción: Marina Califano.]
}

Si con el libro Cuando las imágenes toman posición. El ojo de la historia 1, Georges DidiHuberman expone el concepto de montaje como noción clave para comprender los significados estético-político desarrollado por Bertol Brech en su Arbeitsjournal o Diario de trabajo; y que de acuerdo con el historiador francés, implicó "una toma de posición” por parte del escritor alemán respecto de los acontecimientos históricos que se desarrollaron durante la segunda guerra mundial.2 Con el libro Remontajes al tiempo padecido. El ojo de la historia 2, se nos introduce en la imagen como documento, como archivo, como memoria visual del desastre -campos de concentración, guerras y violencia política- $\mathrm{y}$, a partir de ahí, se lleva a cabo una interpretación sobre aquellas imágenes -cinematográficas y fotográficas- que tienen el potencial de articularse como "imágenes dialécticas"; esto es, como imágenes que son capaces de poner en funcionamiento su propio punto crítico y su campo de cognoscibilidad. En tal sentido, Remontajes al tiempo padecido, se pregunta por el papel que desempeñan las imágenes en la legibilidad de la historia. Es esta inquietud la que atraviesa los dos textos principales y los dos apéndices recopilados en este segundo volumen de $\mathrm{El}$ ojo de la historia.

El primer texto, "Abrir los campos, cerrar los ojos: imagen, historia, legibilidad", se centra en reconstruir los mecanismos y las condiciones de visibilidad y legibilidad de aquellas imágenes cinematográficas que captaron el momento de apertura de los campos de concentración Nazi y su posterior montaje como discursos acerca del horror. Siguiendo los planteamientos teóricos de Walter Benjamin respecto de la legibilidad de la historia y su articulación como visibilidad concreta e inmanente;

Georges Didi-Huberman.Remontajes al tiempo padecido. El ojo de la historia 2. Buenos Aires. Editorial Biblos, 2015, 239 pp. Traducción: Marina Califano. Juan Pablo Silva Escobar,

Autoctonía. Revista de Ciencias Sociales e Historia, Vol. I, N²2, Julio-Diciembre 2017, 303-308

ISSN 0719-8213

DOI:http://dx.doi.org/10.23854/autoc.v0i2.21 
Didi-Huberman propone que las imágenes que logran trascender como mera evidencia son aquellas construcciones visuales que consiguen articularse como índice histórico; es decir, son imágenes que no sólo conjugan un tiempo histórico determinado al cual pertenecen y que eventualmente pueden arrojar luz sobre el pasado; sino que al mismo tiempo exponen un régimen de historicidad, vale decir, manifiestan una suerte de relación social con el tiempo; que hace de la imagen un espacio simbólico en el que tiene lugar aquello que Walter Benjamin llamó "dialéctica en reposo".

Para dar cuenta de la imagen como legibilidad de la historia, Didi-Huberman se focaliza primero en analizar las imágenes que, en 1945, Samuel Fuller filmó durante la liberación del campo de concentración de Falkenau. Se sugiere que esas imágenes, en cuanto "documento en bruto" (p. 46), muestran el intento por humanizar el desastre del exterminio Judío, puesto que los soldados "al intentar abrir un campo, abrieron en el horror un espacio y un tiempo para la dignidad de los muertos" (p. 55, cursivas en el original). Una dignidad que se expresa mediante el ritual funerario organizado por las Fuerzas Aliadas, y que fueron sutilmente registrada por el lente del soldado Fuller. Posteriormente, Didi-Huberman analiza el remontaje que cuarenta años después realiza el cineasta Emil Weiss, quien intenta volver visible y legible, dentro de un contexto actual, los silenciosos veinticinco minutos que filmó
Fuller. Para ello, fue necesario primero adentrarse en un proceso que permitiera "temporalizar las imágenes que nos restan" ( $p$. 30 , cursivas en el original); con la finalidad de abrir los campos bajo un mismo gesto, "de cerrar los ojos de los muertos (gesto ético especialmente necesario en la apertura de un campo) y de mantener los ojos abiertos sobre los muertos (acto de conocimiento $\mathrm{y}$ vigilancia necesarios sesenta años después)" (p. 49, cursivas en el original). Para ello, Weiss convenció a Fuller que volviera no sólo a revisitar el campo liberado -hoy prácticamente destruido- sino también que revisitara y confrontara sus recuerdos con las imágenes que había producido en 1945; de manera que son las imágenes las que interrogan la memoria de Fuller, son las imágenes las que al ser remontadas abren la posibilidad de una dialéctización, pues, "son las imágenes mismas las que, a pesar de su madurez, interrogan al testigo: al tomar la palabra él les devolverá la posibilidad de ser verdaderamente 'miradas', 'leídas', es decir "entendidas"' (p. 51); como un intento por articular lo que Fuller llamó "una breve lección de humanidad” (p. 56).

La lectura que Didi-Huberman hace de estos dos momentos fílmicos en tanto visibilidades que contribuyen en la legibilidad de la historia en un momento de horror y destrucción de la condición humana, nos lleva a pensar acerca de los procesos de cognición que acarrean determinadas construcciones visuales, y como éstas contribuyen a evidenciar y 
temporalizar singularidades en las que brota, "entre el inmenso archivo de textos, imágenes, o testimonios del pasado, un momento de legibilidad y memoria que aparece (...) como un punto crítico" (p. 20). De este modo, la condición de legibilidad de las imágenes de la película muda de 1945 como su posterior remontaje cuarenta años después, emerge lo que Didi-Huberman llama "el momento ético de la mirada" (p. 52). Un momento temporal, dialéctico que no implica una actitud moral o moralizante, sino más bien persigue constituirse como un acto de evidencia, testimonio y memoria respecto del horror padecido y su eventual legibilidad como tiempo histórico. En tal sentido, la emergencia de un conocimiento crítico del pasado se produce gracias al trabajo dialéctico de montaje y remontaje, de inscripción y desciframiento, que hace posible una legibilidad de la historia a través de imágenes dialectilizadas; esto es, de imágenes que manifiestan relaciones, movimientos, intervalos, síntomas y contradicciones, que nos ayudan, como sugiere Didi-Huberman, a abrir los ojos ante la historia, vale decir, pensarla.

El segundo texto, "Abrir los tiempos, armar los ojos: montaje, historia, restitución", analiza la obra del cineasta alemán Harun Farocki y la crítica que éste hace a la producción de imágenes que participan en la destrucción de los seres humanos a través de la violencia política y la guerra. Didi-Huberman detecta en las películas de Farocki una construcción crítica que tiene como punto de partida la utilización "de imágenes que no están 'traducidas' en ningún diccionario preexistente. Filma, recoge, desmonta, remonta" (p. 94). Se trata de una producción y una productividad fílmica que busca poner en circulación interpretaciones que expresen una perspectiva que procura expresar el punto crítico en que la violencia se articula como acontecimiento político.

En consecuencia, se entiende que una crítica de las imágenes requiere fabricar una relación dialéctica, esto es, elaborar un uso, una práctica, una producción de imágenes que conforman núcleos de montaje y remontajes, interpretaciones y deconstrucciones que atañen "a aquello que Walter Benjamin llamó inconsciente de la vista $\mathrm{y}$, que en ese sentido, se dirigen a nuestra mirada como una verdadera crítica de la violencia" (p. 89). Una crítica que pasa por reconocer la instrumentalización que se hace de las imágenes como dispositivos retóricos aparentemente neutros. En segundo término, se trata de admitir que para criticar la violencia es pertinente describirla, para eso -nos dice Didi-Huberman-, es necesario saber mirar y desmontar las construcciones visuales, tensionar las imágenes en cuanto dispositivos y técnicas. Se trata, a grandes rasgos, de describir la relación en que la imagen se constituye no sólo como un instrumento de legibilidad y conocimiento, sino también como un instrumento de dominación. 
A través de las nociones de archivo, legibilidad, restitución y remontaje, Didi Huberman inscribe la producción fílmica de Farocki como una suerte de inteligencia editora que opera sobre las imágenes del mundo. Una de sus particularidades consiste en que sus películas funcionan como una sucesión de ensayos que pretenden hacer de la imagen un asunto que trasciende la mera información para devenir en conocimiento. Siguiendo el famoso texto de Theodor Adorno -"El ensayo como forma"-, DidiHuberman clasifica la cinematografía de Farocki como cine-ensayo que evalúa, fundamenta e interpreta la violencia en sus múltiples adscripciones. Plantea que la legibilidad de la violencia política, de la guerra y de la sujeción de las instituciones disciplinarias acontece en sus películas gracias a una mezcla ingeniosa de exégesis y crítica, mediante la cual se da un proceso de sobreimpresiones; es decir, se trata de yuxtaponer, mesclar y unir diferentes paradigmas de legibilidad mediante los cuales se monta y remonta la violencia del mundo, se construyen y reconstruyen discursividades que nos ayudan a comprender "el sufrimiento del mundo", el cual puede ser aprehendido mediante un trabajo de desclasificación y desmontaje de las imágenes en movimiento en el convencimiento de que éstas "son libres de revisitar -de interpretar, de reconocer, de admirar o no, de remontar nosotros mismos- en tanto que herramientas visuales para comprender el mundo" (p. 170).
En el apéndice 1 titulado "Cuando el humillado mira al humillado" DidiHuberman realiza un trabajo de inscripción acerca de la obra fotográfica que Agustí Centelles realizó en 1939 en el campo de Bram, lugar al que el fotógrafo catalán fue a parar huyendo de la victoria de Francisco Franco. Se sugiere que las fotografías de Centellessonunregistroquedescribenosólo el estado del lugar: sus barracas, callejuelas, lugares de socialización, alambrada, sino también nos inserta dentro de un cierto estado de sujeto, que en este caso responde al estado -y al ojo- del refugiado devenido en un prisionero derrotado. De este modo, las fotografías de Centelles se articulan como un dispositivo visual que expone la realidad del humillado en tanto sujeto que experimenta la humillación, por lo tanto lo que nos da a ver Centelles "es el trabajo mismo de la humillación" (p. 193 cursivas en el original). De acuerdo con Didi-Huberman estas imágenes están marcadas por una doble distancia en la medida en que no es son sólo el trabajo de la humillación el que se nos da a ver (hombres defecando todos juntos para luego transportar grandes bidones de mierda común), sino que al mismo tiempo es un trabajo en contra de la humillación lo que se exterioriza con estas fotografía y, con ello, busca dar a ver (y a entender) las condiciones visuales de aparición del campo de Bram como un lugar de lo ominoso. Aunque signado como un campo "blando"-en comparación a las condiciones de los campos de prisioneros 
nazis-; el campo de Bram -mediatizado por el lente de Centelles- exhibía una cierta "blandura de estado", en la medida que el campo debía "albergar" es decir "proteger", salvaguardar, cuidar a los refugiados de la guerra civil española, y no comportarse como ese círculo de infierno, de miseria, de humillación y muerte que vemos en la mayoría de las fotos. De ahí que las imágenes de Centelles se articulan como una mirada política que revela el punto crítico en el que los refugiados son acogidos como rehenes, como reclusos despojados de su condición política. La potencia visual de estas fotografías de 1939 se localiza en el acto de desplazamiento desde donde el humillado mira al humillado y, con ello, expone una imagen que pretende articular una legibilidad de la historia desde la experiencia padecida que, en última instancia, "modifica la perspectiva temporal que deviene [en] experiencia adquirida, la de una experiencia susceptible a ser transmitida en el futuro" (p. 199).

Finalmente, el libro se cierra con el apéndice 2 que lleva por título "Gran juguete mortal". Aquí se nos introduce en la obra del artista visual Christian Boltanski quien a través de instalaciones conceptuales, fotografías y video arte nos interpela a pensar la imagen desde una ontología de lo semejante. "Toda su obra vacila entre la posibilidad de una empatía y la imposibilidad del solipsismo, la terrible compasión para con los otros y la no menos terrible soledad de nuestra posición en la especie humana" (p.
209). Por otro lado, la obra de Boltanski se articula como un trabajo desde/sobre la memoria, una suerte de desmenuzamiento del tiempo a partir del cual se busca articular un discurso visual que procura conjugar un yo ficcionalizado. Un yo "que a menudo parece hablar de él (...) cuando no hace, en realidad, sino hablar de los otros, es decir de nosotros, de todos nosotros, desde ese ángulo finalmente impersonal de la especie humana confrontada con la historia" (p. 210). Didi-Huberman sugiere que en la obra de Boltanski se configura como un montaje de las cosas pequeñas, intrascendentes -como su puesta en escena de un montón de ropa usada- que gracias a un efecto de refracción cambia el sentido de esas cosas insignificantes, banales o cotidianas, y las consagra bajo una forma reconocible de aura cultural. Un aura que trasciende la mimesis e instala el sentido -mítico si se quiere- como una cuestión que nos involucra a todos y todas. De este modo las instalaciones, las imágenes y el video arte de Boltanski son siempre un intento utópico por consagrar una obra al colectivo en donde el público "debería sentirse individualmente reconocido, concernido, mirado. No es el espectador que paga su entrada al Gran Palais el que debe 'reconocer' la obra, sino la obra misma la que debe 'reconocer' a cada uno que la mira" (p. 209).

En suma, la invitación que nos hace Georges Didi-Huberman es a intentar abrir los ojos ante la historia. Abrirlos a 
través de las mediaciones visuales -cine, fotografía, plástica- implica preguntarse por la productividad de las imágenes en la legibilidad de la historia; implica intentar hacer visible, es decir entendible, aquellos procesos que se encuentran inscritos en la construcción (montaje, remontaje, desmontaje) de la memoria visual del desastre, del disciplinamiento y de la violencia política. Por otro lado, abrir los ojos ante la historia implica entender que la idea de la legibilidad de la historia a través de mediaciones visuales y audiovisuales se produce en y por el proceso de montaje $\mathrm{y}$ remontaje de aquello que ha sido capturado en un momento específico, y nos introduce tanto en la idea de la imagen como acontecimiento -histórico, social, político- como en la idea de las imágenes en tanto documento, archivo y reducto en el que tiene lugar la posibilidad de temporalizar un determinado testimonio visual que, al ser dialectizado dentro de un contexto histórico particular, contribuye en la legibilidad de la historia.

\section{Notas}

$1 \quad$ El presente texto se enmarca dentro del proyecto FONDECyT \# 11160133, "Cine, neoliberalismo y sociedad. Por una genealogía de la representación de la pobreza en el cine de ficción chileno (1980-2015)".

2 Didi-Huberman plantea que la toma de posición que asume Bertol Brech consistió en la toma de conciencia acerca de las consecuencias de la guerra; y como esas consecuencias pueden ser leídas y mostradas a partir de un "efecto de distanciamiento" que entrecruza, teje y critica dialécticamente una memoria histórica que intenta ofrecer una perspectiva épica y lírica de la guerra, y que el escritor alemán expone a través de sus fotoepigramas. 